\title{
PERFORMANCE OF ORGANOMINERAL FERTILIZER IN WINTER AND RAINY POTATO CROP
}

\author{
PERFOMANCE DO FERTILIZANTE ORGANOMINERAL NA SAFRA DE INVERNO \\ E DAS ÁGUAS NO CULTIVO DA BATATEIRA
}

\section{Atalita Francis CARDOSO ${ }^{1}$; Regina Maria Quintão LANA ${ }^{2}$; Walyson SOARES ${ }^{3}$; Joicy Vitória Miranda PEIXOTO ${ }^{4}$; José Magno Queiroz LUZ}

1. Doutora em Fitotecnia pela Universidade Federal de Uberlândia, Uberlândia, MG, Brasil. atalitacardoso@yahoo.com.br; 2. Professora e pesquisadora da Universidade Federal de Uberlândia, Instituto de Ciências Agrárias, Uberlândia, MG; 3. Mestrando em Fitotecnia pela Universidade Federal de Uberlândia, Uberlândia, MG, Brasil; 4. Doutoranda em Fitotecnia pela Universidade Federal de Uberlândia,

Uberlândia, MG, Brasil; 5. Professor e pesquisador da Universidade Federal de Uberlândia, Instituto de Ciências Agrárias, Uberlândia, MG

\begin{abstract}
The Agata potato is the most important economic sources of food in Brazil. However, fertilization for this crop has been carried out incorrectly, increasing production costs. Thus, the use of organomineral fertilizer reduces the amount of nutrient applied, facilitates the release of nutrients more slowly and brings improvement in the chemical, physical and biological attributes of the soil. The objective of this work was to evaluate the efficiency of organomineral fertilizers rates and comparate with mineral source on the potato crop in differents seasons. The experimental design was in randomized blocks, with five rates and four replications in the winter season. In the harvest of the rainy season the experiment consisted of 6 rates and four replications. Treatments were 1629.0; 2444.0; 3258.0; $4073.0 ; 4887.0 \mathrm{~kg} \mathrm{ha}^{-1}$ of the organomineral fertilizer which equals $40 ; 60 ; 80 ; 100$ and $120 \%$ of the rate in relation to the mineral fertilizer of $2800 \mathrm{~kg} \mathrm{ha}^{-1}$ of formulation $03-32-06$. There weren ${ }^{\prime}$ significant difference of the organomineral fertilizer in relation to the mineral in the total, commercial and special class of tubers in the winter crop. In the harvest of rainy crop, the average total productivity of potato tubers at all rates of organomineral fertilizer was $29 \mathrm{t}^{-1}$, which represents $22 \%$ higher than mineral fertilizer. The organomineral fertilizer presented agronomic efficiency for potato cultivation and could replace NPK mineral sources. The $4887.0 \mathrm{~kg} \mathrm{ha}^{-1}$ organomineral rate generated higher total yield, commercial and special class of tubers.
\end{abstract}

KEYWORDS: Solanum tuberosum. Organic fertilization. Tubers.

\section{INTRODUCTION}

The potato crop originates in the Andean highlands of South America and represents one of the most economically important sources of food in Brazil (GARCIA, 2015; SILVA, 2014). The cultivar of potato most planted by the producers is $\mathrm{cv}$. Agate, which is characterized by desirable characteristics due to early tuberization, good tuber appearance and productivity (PINELI, 2006; SILVA, 2013).

In Brazil, potato planting can be carried out in all months of the year depending on the specific climatic conditions of each region. The planting is carried out in three harvests: 1st harvest - from the rainy season (August to November), 2nd crop - dry season (January to March) and 3rd harvest - winter season (May to July) (CARDOSO et al., 2015).

The first harvest represents $50 \%$ of the Brazilian production of tubers and the average productivity reached by the producers in the state of Minas Gerais in the year 2015 was $30.62 \mathrm{t} \mathrm{ha}^{-1}$ (SECRETARIA DE ESTADO DE AGRICULTURA, 2015; CARDOSO et al. 2015).
This crop is characterized by the high cost of production due to the application of pesticides and pest and disease control products, which are favored by climatic conditions such as precipitation and temperature. In the third crop, it is characterized by the use of a technological package to increase tuber productivity, which is superior to that of water because of the need to use supplementary irrigation (CARDOSO et al., 2015).

The use of high mineral fertilizers rates is one of the factors that increase the costs for potato production, which can lead to a negative response as nutritional imbalance, soil compaction due to increased input use and environmental contamination (MESQUITA et al. 2012).

According to Ferreira (2015) the mixture of mineral fertilizers and organic waste minimizes the environmental impact, increases soil fertility and also reduces the use of mineral fertilizers, converting many advantages to the producer. The organomineral fertilizer facilitates the release of nutrients, promotes improvement in the physical, chemical and biological attributes of the soil. The main advantages related to these attributes are: 
cation exchange capacity increase, nutrient availability in a slower way and as a consequence less leaching of these, greater aeration, water retention, better soil aggregation, favors the increase of beneficial microbial activity, complexation of heavy metals and maintenance of $\mathrm{pH}$ balance (CARDOSO, 2015a; FERREIRA, 2015).

There are few results for the use of organomineral fertilizer in potatoes. However, for maize crop, the productivity of the crop was higher in the $600 \mathrm{~kg} \mathrm{ha}^{-1}$ dose of the organomineral fertilizer, not differing from the treatments that used $200 \mathrm{~kg} \mathrm{ha}^{-1}$ mineral And $300 \mathrm{~kg} \mathrm{ha}^{-1}$ organomineral. The same author concludes that organomineral fertilization can replace, in a viable way, the conventional mineral fertilizer to obtain high crop productivity (TIRITAN; SANTOS, 2012).

Thus, the objective of this work was to evaluate doses of organomineral fertilizer in comparison with the mineral source of immediate release in potato yield, Agata cultivar, in different crops: winter harvest and harvest of the waters.

\section{MATERIAL AND METHODS}

The work was carried out in areas provided by the agricultural company Wehrmann ${ }^{\circledR}$ in municipality of Cristalina, Goiás, with altitude of $1189 \mathrm{~m},\left(16^{\circ} 46^{\prime} 07\right.$ "S and 47 36 '49 "W), soil classified as LATOSSOLO VERMELHO distrófico (LVd), of clayey texture (FERREIRA, 2010a). The climate of the region is considered tropical type $\mathrm{Cwb}$ according to Koppen classification.

The data of average precipitation, maximum and minimum temperature occurred during the period of the conduction of the experiments are in table 1.

Table 1. Average precipitation - $\mathrm{P}(\mathrm{mm})$ and maximum temperatures $-\mathrm{T} \max \left({ }^{\circ} \mathrm{C}\right)$ and minimum $-\mathrm{T} \min \left({ }^{\circ} \mathrm{C}\right)$ in winter and rainy season.

\begin{tabular}{cccccccc}
\hline & \multicolumn{2}{c}{ Winter } & \multicolumn{3}{c}{ Rainy } & \\
& $\mathrm{P}$ & T mín & T máx & & $\mathrm{P}$ & T mín & T máx \\
\hline May & 3,40 & 14,80 & 22,66 & Oct & 0,00 & 18,00 & 34,20 \\
Jun & 0,00 & 14,20 & 21,23 & Nov & 2,66 & 19,13 & 27,46 \\
Jul & 0,00 & 13,00 & 24,19 & Dec & 3,10 & 17,90 & 29,77 \\
Agu & 0,00 & 14,00 & 26,40 & Jan & 5,73 & 19,09 & 27,09 \\
& & & & Feb & 2,11 & 18,43 & 27,25 \\
\hline
\end{tabular}

Source: INMET (2015)

The experiments was carried out in the winter crop in 2012, in the period between May 26 to October 29 and rainy crop was carried out in 2012/2013 at October 29 to February 16, 2013.

The chemical analysis of the soil to characterize the area, performed in the superficial layer of $0-0.20 \mathrm{~m}$ depth according to the methodology described by Donagena et al. (2011) presented the following results: $\mathrm{P}\left(\mathrm{mg} \mathrm{dm}^{-3}\right)=50 ; \mathrm{K}$ $\left(\mathrm{mg} \mathrm{dm}^{-3}\right)=161 ; \mathrm{pH}\left(\mathrm{H}_{2} \mathrm{O}\right)=6.4 ; \mathrm{Ca}^{2+}\left(\mathrm{cmol}_{\mathrm{c}} \mathrm{dm}^{-3}\right)$
$=5.4 ; \mathrm{Mg}^{2+}\left(\mathrm{cmol}_{\mathrm{c}} \mathrm{dm}^{-3}\right)=1.0 ;$ The soil had no aluminum; Base saturation of $77 \%$ and cation exchange capacity of $88 \mathrm{mmol}_{\mathrm{c}} \mathrm{dm}^{-3} ; \mathrm{H}+\mathrm{Al}$ $\left(\mathrm{cmol}_{\mathrm{c}} \mathrm{dm}^{-3}\right)=2.0$; Organic matter of $3.6 \mathrm{~g} \mathrm{dm}^{-3}$.

The experimentals design were a randomized complete block design, with five rates of organomineral fertilizer with four replications and a control treatment (chemical mineral fertilizer rate) (Table 2).

Table 2. Fertilizer rates $\left(\mathrm{kg} \mathrm{ha}^{-1}\right)$ used in the experiments.

\begin{tabular}{ccc}
\hline Fertilizer & $\begin{array}{c}\text { Percentage corresponding to } \\
\text { mineral fertilizer }\end{array}$ & $\begin{array}{c}\text { Rates } \\
\left(\mathrm{kg} \mathrm{ha}^{-1}\right)\end{array}$ \\
\hline Mineral & & 2800,00 \\
$(3-32-8)$ & $40 \%$ & 1629,0 \\
Organomineral & $60 \%$ & 2444,0 \\
Organomineral & $80 \%$ & 3258,0 \\
Organomineral & $100 \%$ & 4073,0 \\
Organomineral & $120 \%$ & 4888,0 \\
\hline Organomineral & & \\
\hline
\end{tabular}

The plots in the winter harvest consisted of

6 lines with $0.8 \mathrm{~m}$ between rows and $10 \mathrm{~m}$ of length, 
totaling $48 \mathrm{~m}^{2}$ per plot. The evaluations were carried out in the two $14.4 \mathrm{~m}^{2}$ central lines, with the edges located on the lines on each side and the initial and final half-meters of each block being neglected.

In the harvest of the waters, the experiment contained 28 plots, consisting of 8 rows with $0.8 \mathrm{~m}$ between rows and $8 \mathrm{~m}$ long, totaling $51.2 \mathrm{~m}^{2}$ of area per plot. The evaluations were carried out in the two central lines of $11 \mathrm{~m}^{2}$ scoring the borders located in the two lines on each side and half a meter initial and final of each plot.

The rates of organomineral fertilizer were fixed according to recommendations for potato cultivation using mineral fertilizer (SOUZA; LOBATO, 2004). The source of NPK of mineral fertilizer was formulated 3-32-6 with $6.7 \%$ of $\mathrm{N}$, $78 \%$ of $\mathrm{P}_{2} \mathrm{O}_{5}$ and $10.3 \%$ of $\mathrm{K}_{2} \mathrm{O}$ using the sources urea, triple superphosphate and potassium chloride. For the production of organomineral fertilizer was made A chicken bed compost by means of a controlled decomposition aerobic process with an average duration of 20 days. To reduce the composting period, nutrient and microorganism cocktails (fungi and bacteria) were used to accelerate the decomposition process, obtaining, in a few days, the stabilized compound. The mineral sources urea, triple superphosphate and potassium chloride were added to the compound aiming at the balance of nutrients according to the requirement of the potato crop and the ability of the soil to provide the nutrients. Subsequently, the material was homogenized and pelletized (TEIXEIRA, 2013).

The organomineral fertilizer pellets have a high hardness ( $8 \mathrm{kgf} \mathrm{cm}^{-2}$ ), which means high breaking strength and the prevention of the formation of ununiform particles. The organic matter exerts the physical protection, forms a porous matrix around the nutrients, it prevents the direct contact of soluble nutrients with the soil. As a consequence, it promotes lower losses by fixation and leaching (TEIXEIRA, 2013).

The chemical characterization of the organomineral fertilizer used in the experiments is presented in Table 3.

Table 3. Chemical parameters of organomineral and mineral fertilizers used (\%).

\begin{tabular}{ccc}
\hline Nutrients & $\begin{array}{c}\text { Mineral } \\
(3-32-6)\end{array}$ & $\begin{array}{c}\text { Organomineral } \\
(2-22-4)\end{array}$ \\
\hline Calcium $(\mathrm{Ca})$ & 2,00 & 1,40 \\
Sulfur $(\mathrm{S})$ & 2,00 & 1,40 \\
Magnesium $(\mathrm{Mg})$ & 1,50 & 1,10 \\
Boron $(\mathrm{B})$ & 0,20 & 0,14 \\
Cupper $(\mathrm{Cu})$ & 0,10 & 0,07 \\
Manganese $(\mathrm{Mn})$ & 0,15 & 0,11 \\
Zinc $(\mathrm{Zn})$ & 0,14 & 0,14 \\
\hline
\end{tabular}

The preparation of the soil area was recommended for the potato crop, by means of a plowing followed by trenching / leveling and later opening of the furrows (FILGUEIRA, 2008).

Fertilization was done manually, with incorporation through hoes, in the planting grooves, where the potatoes were planted cv. Agate type 3 (tubers with a diameter of 30 to $40 \mathrm{~mm}$ ).

In the planting grooves of all plots, $30 \mathrm{~kg}$ $\mathrm{ha}^{-1}$ of a source of macro and micronutrients composed of $2.7 \%$ of $\mathrm{Ca} ; 8.2 \%$ of $\mathrm{S} ; 12 \%$ of $\mathrm{Zn}$ and $6 \%$ of $\mathrm{B}$ according to the recommendation of Souza and Lobato (2004) for the potato crop.

During the two planting seasons, about 30 days after planting, the heap was used to stimulate plant tuberization. In the winter harvest, the fertilization in the cover with $300 \mathrm{~kg} \mathrm{ha}^{-1}$ of the formulated 20-00-20 was performed together with the heap. Coverage was not applied in the harvesting of the rainy crop with the purpose of verifying the effect of the slow release of the organomineral fertilizer.

The irrigation system used was aspersion by central pivot. The plants received approximately $500 \mathrm{~mm}$ of water during the cycle, being close to the volume of water indicated for cultivation, which varies from 450 to $550 \mathrm{~mm}$.

After harvest, to obtain productivity at $\mathrm{t} \mathrm{ha}^{-1}$, the tubers were weighed and graded. The classification was made according to the diameter of the tubers and in the classes: Special $(42-70 \mathrm{~mm})$, Second (33-42 $\mathrm{mm})$, First (28-33 $\mathrm{mm})$, Miscellaneous (up to $28 \mathrm{~mm}$ ) and discarded (damaged tubers, Non-commercial). The characterization of the commercial productivity was made by the sum of the income of the Special, Second and Diverse classes, which are the classes accepted by the market. The standard for classification used was that used by the potato processing industries (FAEP, 2015). 
Data were submitted to analysis of variance. For the comparison of the means of the mineral fertilizer treatment and the treatments with organomineral fertilizer, the Dunnett test, $5 \%$ of significance, was applied with the program SPSS for Windows Release 8.0 (1998). Data on treatments with organomineral fertilizer were submitted to polynomial regression analysis using the SISVAR statistical program (FERREIRA, 2000b).

\section{RESULTS AND DISCUSSION}

The efficiency of organo mineral fertilizers in was evaluate through of the yield of tubers in relation that mineral fertilizer at rainy and winter crop Tables 4 and 5. The total productivity of tubers in this harvest at winter crops were no differences between mineral fertilizer rate and organomineral fertilizers rates by Dunnet test ( $\mathrm{p}>0.05$ ) Table 4.

In the winter crops the average total productivity was $41.05 \mathrm{t} \mathrm{ha}^{-1}$.Recently, Brazilian producers found a yield of $33.8 \mathrm{t} \mathrm{ha}^{-1}$ in the winter harvest. This value is below that obtained by Cardoso et al. (2015a) of $40.64 \mathrm{t} \mathrm{ha}^{-1}$ in this crop under organomineral fertilization at planting and cover with mineral source (Table 4).

Table 4. Total and commercial tubers productivity and classification of Agata potato under winter crop.

\begin{tabular}{|c|c|c|c|c|c|c|c|}
\hline $\begin{array}{c}\text { Rates } \\
\left(\mathrm{kg} \mathrm{ha}^{-1}\right)\end{array}$ & ----Pro & $\begin{array}{l}y---- \\
\left(t_{\text {ha }}^{-1}\right)\end{array}$ & & & $\begin{array}{r}-- \text { Classi } \\
\text { (t ha }\end{array}$ & tion----------- & \\
\hline \multirow[t]{2}{*}{2800,00 (mineral) } & Total & Commercial & Special & Second & Diverse & $\begin{array}{c}\text { No } \\
\text { commercial }\end{array}$ & Doll \\
\hline & 43,1 & 41,40 & 37,40 & 3,30 & 0,70 & 0,80 & 0,90 \\
\hline $1629,10(40 \%)$ & 41,6 & 39,7 & 35,60 & 3,60 & 0,50 & 0,90 & 1,0 \\
\hline $2443,60(60 \%)$ & 42,6 & 39,0 & 35,60 & 2,90 & 0,50 & 0,90 & 2,7 \\
\hline $3258,20(80 \%)$ & 41,7 & 39,7 & 35,60 & 3,50 & 0,60 & 0,90 & 1,1 \\
\hline $4072,70(100 \%)$ & 42,5 & 39,5 & 34,90 & 4,00 & 0,60 & 0,80 & 2,2 \\
\hline $4887,30(120 \%)$ & 34,8 & 33,6 & 31,10 & 2,20 & 0,30 & 0,50 & 0,7 \\
\hline
\end{tabular}

Averages followed by $*$ differ significantly in relation to control treatment by Dunnet test $(p>0.05)$

The total productivity of tubers in this harvest at rainy crop was significant from the rate of 2443,60 kg ha ${ }^{-1}$ with (Table 5). Table 2 shows the percentage of organic fertilizer fertilizers in the range of 3258.20 and $4887.30 \mathrm{~kg} \mathrm{ha}{ }^{-1}$, corresponding $80 \%$ and $120 \%$ of the mineral rate. In addition, the special class, at $3258.20 \mathrm{~kg} \mathrm{ha}^{-1}$ of organomineral fertilizer, presented higher productivity than the Brazilian average of $27.80 \mathrm{tha}$ ${ }^{1}$, according to Ibge (2014). The organic matter that compose the organomineral fertilizer may have been essential to stimulate soil microorganisms to release nutrients gradually and have resulted in productivity higher than the Brazilian average in the harvest of the rainy crop.

The total average productivity of potato tubers cv. Agata in the rainy crop harvest was $29 \mathrm{t}$ $\mathrm{ha}^{-1}$ in all evaluated rates of organomineral fertilizer, which represents $22 \%$ higher than mineral fertilizer (Table 5). This result was higher than the productivity of $26.5 \mathrm{t} \mathrm{ha}^{-1}$ found by potato farmers in the region of Parana state in the harvest of 2015/2016 at rainy crop.

Table 5. Total and commercial tubers productivity $\left(\mathrm{t} \mathrm{ha}^{-1}\right)$ and classification under rainy crops.

\begin{tabular}{|c|c|c|c|c|c|c|c|}
\hline $\begin{array}{c}\text { Rates } \\
\left(\mathrm{kg} \mathrm{ha}^{-1}\right)\end{array}$ & \multicolumn{2}{|c|}{$\begin{array}{l}\text {-----Productivity--- } \\
\left(\mathrm{t} \mathrm{ha}^{-1}\right)\end{array}$} & \multicolumn{5}{|c|}{$\begin{array}{c}\left.{ }^{-1} \mathrm{t} \mathrm{ha}^{-1}\right) \\
\end{array}$} \\
\hline \multirow[t]{2}{*}{2800,00 (mineral) } & Total & Commercial & Special & Second & Diverse & $\begin{array}{c}\text { No } \\
\text { commercial }\end{array}$ & Doll \\
\hline & 22,61 & 21,79 & 19,31 & 2,26 & 0,22 & 0,73 & 0,09 \\
\hline $1629,10(40 \%)$ & 27,68 & 27,31 & 24,11 & 2,96 & 0,24 & 0,33 & 0,04 \\
\hline $2443,60(60 \%)$ & $31,74^{*}$ & $31,32 *$ & $28,09 *$ & 2,98 & 0,25 & 0,42 & 0,17 \\
\hline $3258,20(80 \%)$ & $39,91 *$ & $38,95^{*}$ & $35,17 *$ & 3,50 & 0,28 & 0,76 & 0,31 \\
\hline $4072,70(100 \%)$ & $34,98 *$ & $34,32 *$ & $30,80 *$ & 3,14 & 0,38 & 0,64 & 0,02 \\
\hline $4887,30(120 \%)$ & $39,42 *$ & $38,32 *$ & $35,86^{*}$ & 2,11 & 0,35 & 0,83 & 0,27 \\
\hline
\end{tabular}

Averages followed by $*$ differ significantly in relation to control treatment by Dunnet test $(\mathrm{p}>0.05)$

According to Cardoso et al. (2015 b) there weren't significant differences in the comparison between mineral and organomineral fertilizer tested in the winter harvest in evaluation of total yield of 
tubers cv. Atlantic. Already in rainy crop, there was difference in the comparison between the mineral and organomineral. The maximum estimated productivity was $27 \mathrm{t} \mathrm{ha}^{-1}$ at the organomineral rate of $3500 \mathrm{~kg} \mathrm{ha}^{-1}$ corresponding to $85.90 \%$ of the organomineral fertilizer rate in relation to the mineral.

In regions of high altitude the temperature decreases in average of $0,6^{\circ} \mathrm{C}$ for each $100 \mathrm{~m}$ of elevation (PEREIRA et al., 2007). The Cristalina region has an altitude of $1189 \mathrm{~m}$ and this result in favorable conditions for the growth and development of potato in the winter season and explains the differences between yields in the evaluated harvests.

The mild temperatures influence in a lower respiratory rate and greater reserve accumulation, less occurrence of pests and disease pressures for the culture and nights with mild temperatures are favorable to thermoperiodicity of the plant, that is, the potato needs a daily variation of $10^{\circ} \mathrm{C}$ (Nocturnal) and $20^{\circ} \mathrm{C}$ (diurnal) to achieve high productivity (FILGUEIRA, 2008; PEREIRA et al., 2007).

Table 4 shows that there weren`t significant difference in the total and commercial yield of tubers, however, it was observed that the total productivity in the winter crop was $47 \%$ higher than the rainy crop and the special class was $48 \%$ higher in this crop (Tables 4 and 5). The results suggest that the productivity differential between the winter and the rainy crops may have occurred due to climatic conditions, with emphasis on temperature (Table 1).

In the rainy crop occurs greater temperature variation and precipitation, in this condition the productivity of the crop is smaller in relation to the winter crop due to the occurrence of pests and diseases being more favorable to the plant. Nights with higher temperatures favor energy expenditure by increasing the respiratory rate of plants, and thus, the tubers produced in these conditions will be of reduced size and weight due to the less accumulation of photoassimilates produced during the day. The potato is a plant C3 and sensitive to high air temperatures that result in the reduction of photosynthetic rate due to the reduction in the efficiency of photosystem II, increased respiration and reduction of leaf area (FAGUNDES et al., 2010).

The potato tubers of the discard and doll class decreased, respectively, $25 \%$ and $89 \%$ in the rainy crop compared to the winter crop (Tables 4 and 5). It was observed probably due an increase in the quality of the tubers for effect of slow release of the nutrients by the organomineral fertilizer, because in the winter harvest the supply of these essential elements by immediate source in cover could have been fundamental to increase the number of tubers of the class discard and Doll (Tables 4 and 5). Already Aguilar (2015) found yield for tubers of potato cv. Cupid of the class discarded $6.94 \mathrm{t} \mathrm{ha}^{-1}$ in plots treated with mineral fertilizer in the winter crop, not differing with doses of organomineral fertilizer.

In the regression analyse for the organomineral rates in the winter season it was observed that there was no significant difference for total, commercial and special class $\mathrm{p}>0.05$ - Table 6.

Table 6. Analysis of variance, cultivar Agata, according to the different rates of organomineral fertilizer, in the winter crop.

\begin{tabular}{ccccccccc}
\hline & \multicolumn{4}{c}{ Productivity } & \multicolumn{3}{c}{ Class } \\
\hline SV & L & Total & Commercial & Special & First & Diverse & Boneca & $\begin{array}{c}\text { No- } \\
\text { commercial }\end{array}$ \\
\hline Rates & 3 & $0,98^{\text {ns }}$ & $0,90^{\text {ns }}$ & $0,90^{\text {ns }}$ & $0,46^{\text {ns }}$ & $0,11^{\text {ns }}$ & $0,09^{\text {ns }}$ & $0,98^{\text {ns }}$ \\
Block & 2 & 0,27 & 0,09 & 0,11 & 0,44 & 0,09 & 0,09 & 0,08 \\
Residue & 6 & 18,64 & 18,28 & 16,73 & 0,03 & 0,31 & 1,01 & 0,08 \\
C.V & & 10,16 & 10,66 & 11,34 & 34,39 & 16,17 & 64,14 & 35,89 \\
\hline
\end{tabular}

SV: variation of source; L: degrees of freedom

It was observed in Figure 1 that total, commercial productivity and the special class of potato tubers cv. Agata were higher, at constant rates, in the treatments that used higher organomineral fertilizer rates in the rainy crop.
These yields were found to be 40,33; 39,20 and $35,98 \mathrm{t} \mathrm{ha}^{-1}$, respectively, and the highest rate yielding this yield was $4887.0 \mathrm{~kg} \mathrm{ha}^{-1}$ of the organomineral fertilizer which is equivalent to $120 \%$ of the immediate release mineral source. 

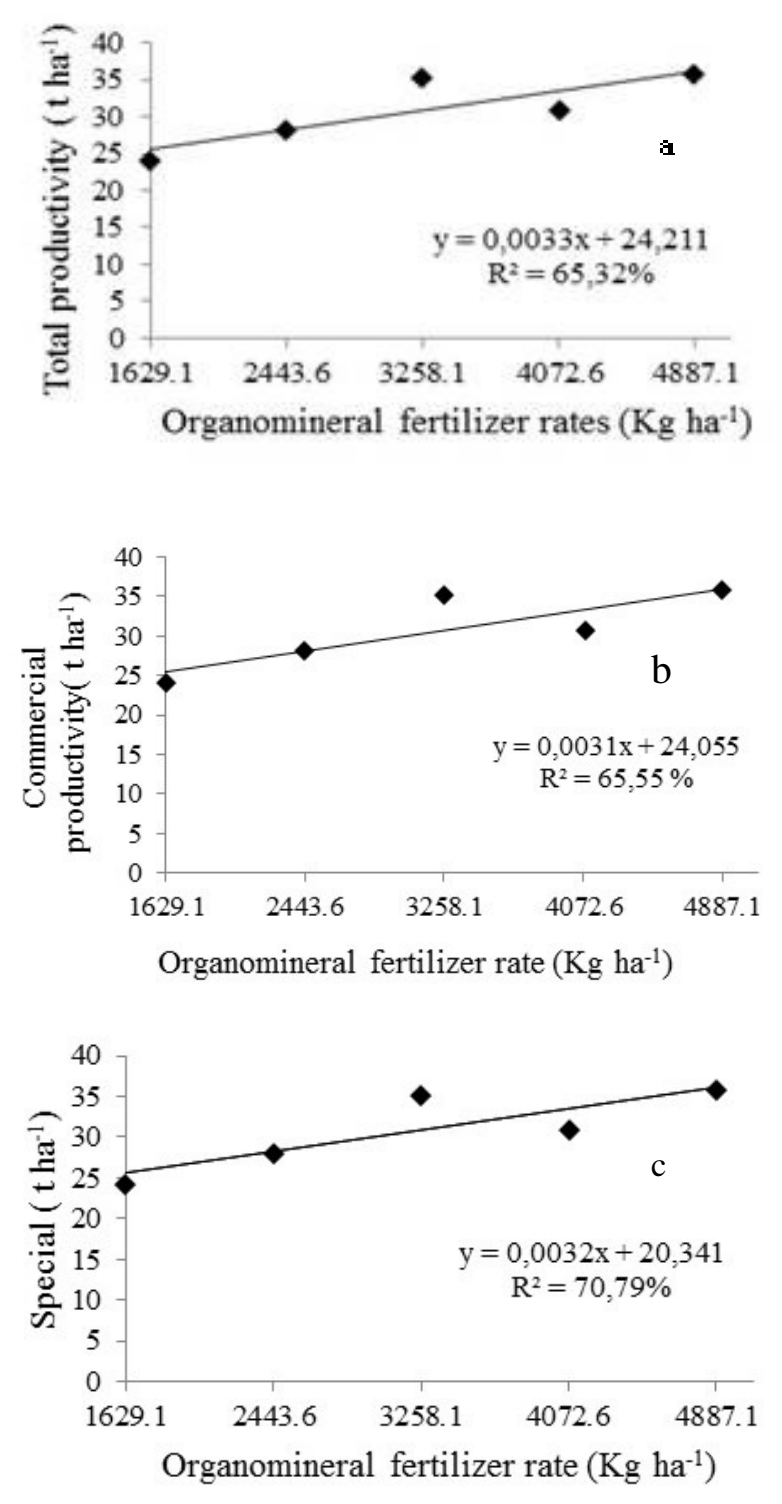

Figure 1. Total (a), Commercial (b) and Special class (c) $\left(\mathrm{t} \mathrm{ha}^{-1}\right)$ of tubers in function of organomineral rates in rainy crop

It was observed that there was no significant difference for first, diverse, doll and no-commercial organomineral fertilizer in the winter season for $\mathrm{p}>$ class yield as a function of the rates of 0.05 - Table 7.

Table 7. Analysis of variance, cultivar Agata, according to the different rates of organomineral fertilizer, in rainy crop.

\begin{tabular}{cccccc}
\hline & & \multicolumn{4}{c}{ Class } \\
\hline FV & L & First & Diverse & Doll & $\begin{array}{c}\text { No- } \\
\text { commercial }\end{array}$ \\
\hline Rates & 3 & $0,31^{\text {ns }}$ & $0,69^{\text {ns }}$ & $0,36^{\text {ns }}$ & $0,31^{\text {ns }}$ \\
Block & 2 & 0,16 & 0,50 & 0,06 & 0,48 \\
Residue & 6 & 0,64 & 0,02 & 1,42 & 0,11 \\
C.V & & 27,13 & 52,63 & 141,15 & 58,75 \\
\hline
\end{tabular}


According to Souza et al. (2012), the effect of the slow release of the nutrients of the organomineral fertilizer is due to the conditions of temperature, pressure and humidity used in the transformation of the compound into pellets. Therefore, the mineral phase of this fertilizer will be protected in the porous organic matrix, which prevents losses by leaching of nitrogen and potassium. Moreover, this effect may bring benefits to plants since they can better utilize the nutrients through the release timing throughout the development of the crop (OLIVEIRA, 2014).

According to Ferreira (2015), the addition of mineral fertilizer to organic fertilizer reduces the mineralization rate of nutrients, mainly NPK, which can reduce quantities applied per area. In addition, organic matter is essential to potentiate the effect of nutrients and act as a conditioning agent for the decomposing minerals, avoiding physical and chemical incompatibility between the fertilizers that make up the formula.

The application of the organomineral fertilizer presents uniformity in the fertilization since the pellets in their composition NPK, micronutrients and organic matter are evenly distributed (AGUILAR, 2016).

Santos et al. (2013) applied $3650.00 \mathrm{~kg} \mathrm{ha}^{-1}$ of organomineral fertilizer and obtained maximum yield of sunflower achenes of $887 \mathrm{~kg} \mathrm{ha}^{-1}$ representing an increase of $33.71 \%$ in relation to the non-fertilized treatment. According to the author, this improvement is attributed by the presence of organic matter in the nutrient supply, in the elevation of humidity and improvement of soil structure, increase in the catatonic exchange capacity, formation of humus-clay complex and release of nutrients from the mineral fraction .

According to Andraus et al. (2015) the growth and development of radish culture was satisfactory at the rate of $2 \mathrm{tha}^{-1}$ for organomineral.
The application of this fertilizer provided a larger root diameter at 17 days after sowing. The superiority of this application was related to the slow and continuous supply of nutrients in relation to the conventional sources of immediate release and improvement of the chemical, physical and biological attributes of the soil. (FILGUEIRA, 2008, LUZ et al., 2010).

According to Cardoso (2014), the maximum productivity of the special class was $27 \mathrm{t} \mathrm{ha}^{-1}$ which corresponds to $86 \%$ of the organomineral rate in the harvest of waters. In the evaluation of the two crops, winter and rainy, the results showed that from $86 \%$ of the rate of organomineral fertilizer in relation to the mineral source there was no increase in the yield of the tubers.

The organomineral fertilizers present in their composition free amino acids that act as hormonal precursors to the rooting process, besides serving as input vehicle of nutrients, being a source of initial energy and the humic acids contained in the organic fraction of the fertilizer stimulates the activity of the microorganisms Of the soil around the root facilitating the release of nutrients (AGUILAR, 2016; FERREIRA, 2015).

The required organomineral fertilizer rate to obtain the same yield with mineral source was obtained by means of the regression equation and it was verified that the organomineral fertilizer was superior presenting rates of 117,126 and $111 \%$ of NDEs - Table 8. It is noticed that to achieve the same total, commercial and special class of tubers of 22.61; 21.79 and $19.31 \mathrm{t} \mathrm{ha}^{-1}$, respectively, of the mineral source of $2800 \mathrm{~kg} \mathrm{ha}^{-1}$ requires rates of less than $40 \%$ of the organomineral. Therefore, this result allows the immediate release source to be replaced by the organomineral fertilizer, since the agronomic efficiency of this one for total, commercial and special class productivity were higher $17 ; 26$ and $11 \%$, respectively.

Table 8. Organomineral fertilizer rates $\left(\mathrm{kg} \mathrm{ha}^{-1}\right)$ to reach the same production of tubers with mineral fertilizer in the harvest of rainy crop - Mineral Equivalent (NDE).

\begin{tabular}{cccr}
\hline Productivy & Rainy & NDE $(\%)$ & Regression equation \\
\hline Total & $-485,15$ & 117 & $\mathrm{y}=0,0033 \mathrm{x}+24,211$ \\
Commercial & $-730,64$ & 126 & $\mathrm{y}=0,0031 \mathrm{x}+24,055$ \\
Special class & $-322,18$ & 111 & $\mathrm{y}=0,0032 \mathrm{x}+20,341$ \\
\hline
\end{tabular}

According to the company Geociclo (2012) in a study with cane soca of third cut, variety IAC 911099 , the application of $211.5 \mathrm{~kg} \mathrm{ha}^{-1}$ of the organomineral fertilizer produced the same $93.8 \mathrm{t}$ ha ${ }^{-1}$ of stalk when using the $500 \mathrm{~kg} \mathrm{ha}^{-1}$ rate of the mineral source corresponding to $35 \%$ of the NDE content in relation to the mineral. The company claims that continuous use of organomineral fertilizer can bring improvement in the chemical and microbiological attributes of the soil over the years.

Oliveira (2014) found in the experimental field corn $16.38 \%$ higher for the organomineral treatment 4-14-8 compared to the commercial mineral source 4-14-8, since both treatments 
received the same amount of NPK. The same author evaluated the differences in yield between treatments and yield of the crop with the use of organomineral fertilizer in three years was 28.75 ; 33.33 and $38.78 \%$ higher than the mineral treatment in the harvests of 2009/2010;2010/2011 and $2011 / 2012$ respectively. The superiority of organomineral treatment is in the supply of organic matter that is not found in mineral fertilizer.

\section{CONCLUSIONS}

The organomineral is efficient to potato crop at rainy and winter crop.

At $4887.0 \mathrm{~kg} \mathrm{ha}^{-1}$, which represents $120 \%$ higher than the mineral source provided higher quality of tubers.

RESUMO: A batata Agata é a principal fonte econômica de alimentos no Brasil. No entanto, a fertilização para esta cultura foi realizada incorretamente, aumentando os custos de produção. Assim, o uso de fertilizante organomineral reduz a quantidade de nutriente aplicado, facilita a liberação de nutrientes mais lentamente e traz melhora nos atributos químicos, físicos e biológicos do solo. O objetivo deste trabalho foi avaliar a eficiência das taxas de fertilizantes organomineral e comparar com a fonte mineral na cultura da batata em diferentes estações. O delineamento experimental foi em blocos ao acaso, com cinco taxas e quatro repetições no inverno. Na safra da estação chuvosa, a experiência consistiu em 5 doses e quatro repetições. Os tratamentos foram 1629,0;2444,0;3258,0;4073,0;4887,0 kg ha-1 do fertilizante organomineral que é igual a 40; 60; 80; 100 e $120 \%$ da dose em relação ao fertilizante mineral de $2800 \mathrm{~kg} \mathrm{ha}^{-1}$ da formulação 03-32-06. Não houve diferença significativa do fertilizante organomineral em relação ao mineral na classe total, comercial e especial de tubérculos na safra de inverno. Na colheita da colheita chuvosa, a produtividade total média dos tubérculos de batata a todas as doses de fertilizante organomineral foi de $29 \mathrm{t} \mathrm{ha}^{-1}$, o que representa $22 \%$ maior que o fertilizante mineral. O fertilizante organomineral apresentou eficiência agronômica para cultivo de batata e pode substituir as fontes minerais NPK. A taxa organomineral de $4887,0 \mathrm{~kg} \mathrm{ha}^{-1}$ gerou maior produção total, classe comercial e classe especial de tubérculos.

PALAVRAS-CHAVE: Solanum tuberosum. Adubação orgânica. Tubérculos.

\section{REFERENCES}

AGUILAR, A. S. Resposta da batata cv. Cupido à fertilização organomineral. 2016. 56f. Dissertação (Mestrado em fitotecnia), Universidade Federal de Uberlândia, Uberlândia-MG, 2016.

ANDRAUS, M. P.; CARDOSO, A. A.; FERREIRA, E. M.; NASCIMENTO, A. R.; SELEGUINE, A. Fontes e doses de biofertilizante e fertilizante ornanomineral na cultura do rabanete. Enciclopédia biosfera, Goiânia, v. 11, n. 21; p. 2015.

CARDOSO, A. D.; ALVARENGA, M. A. R.; MELO, T. L.; VIANA, A. L. S. Produtividade e qualidade de tubérculos de batata em função de doses e parcelamentos de nitrogênio e potássio. Ciência e agrotecnologia, Lavras, v. 31, n. 6, p. 1729-1736, 2007. https://doi.org/10.1590/S1413-70542007000600019

CARDOSO, A. F. Fertilizante organomineral em batata cv. Atlantic. 2014. 186f. Tese (Doutorado em fitotecnia), Universidade Federal de Uberlândia, Uberlândia-MG, 2014.

CARDOSO, F.; CARAZZATO, C. A.; DELEO, J. P. B.; SABIO, R. P. (a) Batata. Hortifruti Brasil, setembro de 2015. Disponível: <http://www.hfbrasil.org.br/br/revista/especial-batata-preco-recorde-nao-e-sinonimo-dealta-rentabilidade.aspx $>$ Acesso em Jan/2016

CARDOSO, A. F.; LUZ, J. M. Q.; LANA, R. M. Q. (b)Produtividade e qualidade de tubérculos de batata em função do fertilizante organomineral e safras de plantio. Revista Caatinga, Mossoró, v. 28, n. 4, p. 80 - 89, 2015.

DONAGENA, G. K.; CAMPOS, D. V. B.; CALDERANO, S. B.; TEIXEIRA, W. G.; VIANA, J. H. M. Manual de métodos de análise de Solos. Rio de Janeiro: Embrapa Solos, 2010. 203p. 
FAGUNDES, J. D.; PAULA, G. M.; LAGO, I.; STRECK, N. A.; BISOGNIN, D. A. Aquecimento global: efeitos no crescimento, no desenvolvimento e na produtividade de batata. Ciência Rural, Santa Maria, v. 40, n. 6, 2010. https://doi.org/10.1590/S0103-84782010005000091

FEDERAÇÃO DE AGRICULTURA DO ESTADO DO PARANÁ (FAEP). 2015. Classificação de tubérculos para cultivares de batata. Disponível em:

<http://www.faep.com.br/comissoes/frutas/cartilhas/hortalicas/batata.htm.> Acesso em mai/2015.

FERREIRA, D. F. SISVAR. (a) Sistema de análise de variância. Versão 5.3. Lavras-MG: Lavras-MG: UFLA, 2010.

FERREIRA, M. M. (b) Caracterização física do solo. In: LIER, Q.J. Física do Solo. Viçosa: SBCS, p.1-27, 2010 .

FERREIRA, D.M. Produção e qualidade de batata cultivar ágata sob adubação mineral e organomineral. $95 f$. 2015. Dissertação (Mestrado em Fitotecnia), Universidade Estadual do Sudoeste da Bahia, Vitória da Conquista-BA, 2015.

FILGUEIRA, F. A. R. Novo Manual de Olericultura: agrotecnologia moderna na produção e comercialização de hortaliças. Viçosa: UFV, 2008, p. 412

GARCIA, E. L.; CARMO, E. L.; PÁDUA, J. G.; LEONEL, M. Potencialidade de processamento industrial de cultivares de batatas. Ciência Rural, Santa Maria, v. 45, n. 10, p. 1742-1747, 2015.

https://doi.org/10.1590/0103-8478cr20140072

GEOCICLO. Avaliação agronômica com cana soca variedade IAC 91 1099. 2012. Disponível em: $<$ http://www.geociclo.com.br/wp-content/uploads/2012/07/Lamina-Geofert_CANA.pdf > Acesso em Out/2016.

INSTITUTO BRASILEIRO DE GEOGRAFIA E ESTATÍSTICA -IBGE. Produção agrícola 2015. Disponível em: < http://www.ibge.gov.br/home/estatistica/indicadores/agropecuaria/lspa/lspa_201610_5.shtm >. Acesso em dez/2015.

INSTITUTO NACIONAL DE METEOROLOGIA - INMET. 2015. Dados históricos meteorológicos 2012 e 2013. Disponível em: <http://www.inmet.gov.br/portal/index.php?r=bdmep/bdmep>. Acesso em Jun/2015.

LUZ, J. M. Q.; OLIVEIRA, G.; QUEIROZ, A. A.; CARREON, R. Aplicação foliar de fertilizantes organominerais em cultura de alface. Horticultura brasileira, Brasília, v. 28, n. 3, 2010.

https://doi.org/10.1590/S0102-05362010000300023

MESQUITA, H. A.; PÁDUA, J. G.; YURI, J. E.; ARAÚJO, T. H. Fertilização da cultura da batata. Informe Agropecuário, Belo Horizonte, v. 33, n. 270, p. 52·61, 2012.

OLIVEIRA, G. R. Validação do processo de digestão e de peletização de cama de aviário para a produção de fertilizante organomineral. 2014. 211f. Dissertação (Mestrado em fitotecnia), Universidade Federal de Uberlândia, Uberlândia-MG, 2014.

PEREIRA, A. R.; ANGELOCCI, L. R.; SENTELHA, P. C. Meteorologia agrícola. Edição Revista e Ampliada, 2007, 202.p. Disponível em:

$<$ http://www.esalq.usp.br/departamentos/leb/aulas/lce306/MeteorAgricola_Apostila2007.pdf> Acesso fev/2016. 
PINELI, L. L. O.; MORETTI, C. L.; ALMEIDA, G. C.; SANTOS, J. Z.; ONUKI, A. C. A.; NASCIMENTO, A. B. G. Caracterização química e física de batatas ágata e monalisa minimamente processadas. Ciência Tecnologia de Alimentos, Campinas, v. 26, n. 1, p. 127-134, 2006. https://doi.org/10.1590/S010120612006000100022

SANTOS, J. F.; WANDERLEY, J. A. C.; JUNIOR, J. R. S. Produção de girassol submetido à adubação organomineral. ACSA - Agropecuária Científica no Semi-Árido, Campina Grande, v. 9, n. 3, p. 38-44, 2013.

SECRETARIA DE ESTADO DE AGRICULTURA. Batata. Belo Horizonte, 2015. Disponível em: http://www.agricultura.mg.gov.br/images/Arq_Relatorios/Agricultura/2015/fev/perfil_batata_fev_2015.pdf> Acesso ago/2016.

SILVA, G. O.; BORTOLETTO, A. C.; PONIJALEKI, R.; MOGOR, A. F.; PEREIRA, A. S. Desempenho de cultivares nacionais de batata para produtividadede tubérculos. Revista Ceres, Viçosa, v. 61, n. 5, p. 752-756, 2014.

SILVA, G. O.; STOKER, G.; PONIJALEKI, R.; PEREIRA, A. S. Rendimento de tubérculos de três cultivares de batata sob condições de estiagem. Horticultura brasileira, Brasília, v. 31, n. 2, 2013.

https://doi.org/10.1590/S0102-05362013000200007

SOUZA, R. T.; HENRIQUE, H. M.; KORNDONFER, G. H. Uso de fertilizante organomineral e a produtividade de híbridos de milho. Geofert, 2012. Disponível em: <http://www.geociclo.com.br/wpcontent/uploads/2012/07/Lamina-Geofert_MILHO.pdf> Acesso em Ago/2016.

SOUSA, D. M. G.; LOBATO, E. Cerrado: correção do solo e adubação. Brasília: Embrapa Informação tecnológica, 2004, p. 219.

SPSS Base 8.0 for Windows User's Guide and SPSS Interactive Graphics 8.0 Chicago, IL: SPSS Inc; 1999.

TIRITAN, C. S.; SANTOS, D. H. Resposta do milho safrinha a adubação organomineral no município de Maracaju-MS. Colloquium Agrariae, Presidente Prudente, v. 8, n. Especial, 2012. 